\title{
The problem of religious evil: Does belief in god cause evil?
}

\author{
Lloyd Strickland ${ }^{1}$ (D)
}

Received: 4 March 2017/Accepted: 12 April 2018/Published online: 17 April 2018

(C) The Author(s) 2018

\begin{abstract}
Daniel Kodaj has recently developed a pro-atheistic argument that he calls "the problem of religious evil." This first premise of this argument is "belief in God causes evil." Although this idea that belief in God causes evil is widely accepted, certainly in the secular West, it is sufficiently problematic as to be unsuitable as a basis for an argument for atheism, as Kodaj seeks to use it. In this paper I shall highlight the problems inherent in it in three ways: by considering whether it is reasonable to say that "belief in God" causes evil; whether it is reasonable to say that belief in God "causes" evil; and whether it is reasonable to say that belief in God causes "evil." In each case I will argue that it is problematic to make such claims, and accordingly I will conclude that the premise "belief in God causes evil" is unacceptable as it stands, and consequently is unable to ground Kodaj's pro-atheistic argument.
\end{abstract}

Keywords Evil · Problem of evil · Religious evil · Religious violence · New atheists

For thousands of years, the claim that religious belief causes evil has often been raised as a complaint against religion by those without religious sympathies. ${ }^{1}$

\footnotetext{
1 See for example Lucretius (2007, pp. 5, 6), Hume (1793, p. 42), Russell (1957, pp. xxiv, 38), Hitchens (2007, pp. 26, 223) and Dawkins (2006, p. 1). Joseph A. Buijs sees the situation differently. He reads Lucretius, Russell, Dawkins et al. as advancing — albeit inchoately — an actual argument for atheism, and attempts to extract this argument, which he terms "the argument from harm," from their work. He formulates the argument thus (2009, p. 45):
}

“(1) Religious adherents inflict numerous harms on fellow human beings.

(2) Religious adherents inflict such harms because of their religious beliefs.

(3) Therefore, religion is harmful to human welfare."

Lloyd Strickland

L.Strickland@mmu.ac.uk

1 Department of History, Politics, and Philosophy, Manchester Metropolitan University, Manchester M15 6LL, UK 
However, in recent years the claim has started to be thought of as the basis of a proatheistic argument capable of threatening the very cogency or normative adequacy of religious belief. ${ }^{2}$ The most notable example of this line of thinking can be found in a 2014 paper by Daniel Kodaj, in which he develops an argument he calls "the problem of religious evil." Kodaj formulates the argument as follows (2014, p. 428):

(1) Belief in God causes evil.

(2) God condemns evil.

(3) Whatever God condemns is objectively wrong.

(4) Therefore, by (1)-(3), belief in God causes something objectively wrong.

(5) Theists should refrain from doing anything that causes something objectively wrong.

(6) Therefore, by (4) and (5), theists should refrain from believing in God. ${ }^{3}$

Kodaj states that "The argument generates normative defeat for theism, portraying theistic belief as normatively self-refuting. If the argument is sound, then religious evil forces the rational theist to give up her faith" (2014, p. 428). Kodaj insists that the problem of religious evil is distinct from the classical problem of evil inasmuch as the various responses made to the latter, in the form of defenses and theodicies, are not effective against the former. He seeks to show this by considering a number of these responses and concluding that none resolves the problem of religious evil. Quite possibly those who develop and endorse these defenses and theodicies would see the matter differently, and feel that they do in fact have the conceptual resources at their disposal to tackle the problem, but I shall not concern myself with that here. Instead, my focus in this paper will be on the first premise of Kodaj's argument, that belief in God causes evil. Although this idea has found widespread acceptance, certainly in the secular West, it is sufficiently problematic as to be unsuitable as a basis for an argument for atheism, as Kodaj seeks to use it. In what follows I shall highlight the problems inherent in it in three ways: first, by considering whether it is reasonable to say that belief in God causes evil; second, by considering whether it is reasonable to say that belief in God causes evil; and lastly, by considering whether it is reasonable to say that belief in God causes evil. In each case I will argue that it is problematic to make such claims, and accordingly I will conclude that the premise "belief in God causes evil" is unacceptable as it stands, and consequently is unable to ground Kodaj's pro-atheistic argument. Before I proceed I feel it worth noting, given the recent concerns raised about bias in philosophy of religion scholarship by Draper and Nichols (2013), that I am agnostic, and therefore am not motivated to

\footnotetext{
${ }^{2}$ For example, we find no argument from religious evil in recent works of pro-atheistic philosophy such as Le Poidevin (1996) or Everitt (2004), nor is anything of the sort mentioned in Oppy (2013), a survey article of pro-atheistic arguments.

3 In a later paper (2016, p. 280), Kodaj offers a simplified formulation of the argument:

"(1) Belief in God causes evil.

(2) If God exists, then God wants us to believe in God.

(3) If God exists, then God does not want us to do anything that causes evil.

(4) Therefore, by (1) and (3), if God exists, then God does not want us to believe in God.

(5) Therefore, by (2) and (4), God does not exist."
} 
defend any particular religion or branch thereof, or even religion in general. My motivation is simply to ascertain whether Kodaj's argument has sufficient force to convince a theist to refrain from believing in God.

\section{Belief in God causes evil}

In order to assess whether it is right to say that belief in God causes evil, as Kodaj maintains, it would be prudent to first understand what exactly he means by "evil." He defines evils as "acts or practices that significantly harm the well-being of individuals or social groups" (2016, p. 277) and "religious evils" as those evils "committed in the name of supernatural beings, often with the explicit approval of religious leaders" (2014, p. 425). His stock examples of religious evils are the Crusades and the witch hunts, both of which were characterized by tortures, mass murder, and child killings, all carried out ostensibly in the name of God. To all intents and purposes, then, Kodaj's notion of religious evil is synonymous with religious violence, that is, violence carried out ostensibly in God's name, in which case "evil" and "violence" may be used as interchangeable terms (and for the time being I shall treat them as such). Indeed, Kodaj explains that his definition of evil is informed by recent works on religious violence, a literature that has grown exponentially in the years following the 9/11 attacks. In light of this burgeoning literature and the bewildering array of claims found therein, it is worth noting what premise 1 of Kodaj's argument does not say. It states that "belief in God causes evil," which is markedly different from saying, as some have, that religious texts are the root cause of evil (e.g. Nelson-Pallmeyer 2003; Young 2008, p. 1), that the apocalyptic thinking prevalent in many religions causes evil (e.g. Canadian Security Intelligence Service 2002; Jones 2008, pp. 46, 47), or that religion in general causes evil (e.g. Dawkins 2006, p. 306; Wellman and Tokuno 2004). Anyone familiar with the literature on the topic will know that these are often cited as causes of religious evil, but that belief in God is not. Indeed, the idea that belief in God causes evil is a peculiar one, boasting little to no scholarly support. A recent survey article by Rowley (2014) identifies no fewer than three hundred claimed contributing causes to religious violence, all drawn from the enormous literature on the topic. It is notable that "belief in God" is not one of them. This is not surprising, given that mere belief in a deity does not, by itself, seem to be a plausible candidate for a cause of evil. In the paradigm cases of religious evil that Kodaj cites, namely the Crusades and the witch trials, it was not the mere belief in God that caused the perpetrators of violence to act as they did. To make their actions intelligible, one would have to look beyond their belief in God to other beliefs, such as (in the case of the Crusades) that God desired them to retake the Holy Land or (in the case of the witch trials) to put to death those suspected of renouncing him. But these auxiliary beliefs are not reducible to belief in God, nor can they be deduced from it. Accordingly, when looking for the cause of religious evil, belief in God is not a plausible candidate. The only way to make it so is to subsume various auxiliary beliefs under it, such that 
when it is said "belief in God causes evil" what is meant is that belief in God along with a number of auxiliary beliefs causes evil. ${ }^{4}$

But even if modified in the way suggested, premise 1 of Kodaj's argument is still too broad. It is all very well supposing that "belief in God" is shorthand for "belief in God along with a number of auxiliary beliefs," but these auxiliary beliefs vary widely between the different religions and even between the different branches and denominations of a particular religion. As Kodaj himself notes (2016, p. 278), there are branches of Christianity that are inherently pacifist; he lists "the Mennonite church, the Quakers, the Amish, and the Church of the Brethren." 5 Belief in the God of Christianity, coupled with the auxiliary beliefs of these denominations, presumably does not cause evil at all. What this means is that the problem of religious evil cannot function as a defeater of monotheism as a whole, as Kodaj supposes, or even of Christianity, but at best only of those denominations whose followers commit evil as a result of their religious beliefs. The argument cannot, in principle, pose any threat to those denominations whose followers are not inspired to evil by their religious beliefs.

Accordingly, premise 1 of Kodaj's argument needs to be modified still further, so that it makes specific reference to the beliefs of a particular branch or denomination of Christianity (or another religion). This introduces a greater degree of fairness in Kodaj's argument, as responsibility for his stock examples of religious evils, namely the Crusades and witch trials, could not reasonably be placed on all Christian denominations (as some were not implicated in these events, and indeed some did not even exist at the times these events occurred), but only on the specific ones that were implicated, namely Catholicism in the case of the Crusades, and Catholicism, Lutheranism, and Calvinism in the case of witch trials. Thus in premise 1, "belief in God causes evil" should be taken to mean "belief in the God of religion X (e.g. Christianity) and all of the auxiliary beliefs bound up with branch or denomination Y (e.g. Catholicism, or Lutheranism, or Calvinism) causes evil." This modification means, of course, that the problem of religious evil will be more limited in scope, in that it can defeat only one denomination at a time (rather than an entire religion, or religion in general, as Kodaj supposed), but that might be considered to be a price worth paying for putting the argument on a more secure footing.

However, it is doubtful that the proposed modification to premise 1 does in fact put the argument on a more secure footing, because the modified premise leads to further problems. Most obviously, how does one determine the auxiliary beliefs that are bound up with a particular denomination? Presumably the auxiliary beliefs in question would be the official beliefs of that denomination, for that is all the denomination can reasonably be held responsible for. To determine what these are, a

\footnotetext{
4 This appears to coincide with Kodaj's own thinking, since he states (2014, p. 427) that religious evil is "evil that is apparently motivated by beliefs about, and is explicitly justified by reference to, the purported dictates of some supernatural entity or principle." The "beliefs" referred to here are clearly auxiliary to the belief in God's existence, even though in the problem of religious evil itself it is only the belief in God that is mentioned. Unfortunately, Kodaj does not identify what these auxiliary beliefs are, or why they should be packaged together with belief in God's existence.

5 And outside of the Christian tradition one could also mention Jainism, noted for its doctrinal commitment to non-violence.
} 
good start would be to look at the catechism of a particular denomination, as this stipulates what followers of the denomination should "officially" believe. However, if the auxiliary beliefs of a particular denomination were taken to be all and only those stated in its catechism, Kodaj's argument would struggle to get off the ground, as the catechisms typically do not include those beliefs often thought to cause evil. The Catholic catechism, for example, says nothing about undertaking Crusades, or displacing Muslims from the Holy Land, or the desirability of killing unbelievers etc. It would be very difficult to make a convincing case that "belief in the God of Christianity and the auxiliary beliefs found in the Catholic catechism" was the cause of the sorts of evils for which Catholicism is sometimes thought responsible. Of course, the Catholic catechism does not exhaust the official beliefs of Catholicism, and the same is true for other denominations. The pronouncements of religious leaders also shape the beliefs that followers of a particular denomination will be expected to hold. So if we are to pin down all of the auxiliary beliefs of Catholics, for example, we will need to move beyond those outlined in the catechism and consider those promoted by the Pope as well. But this too is problematic, for in this case there will be no stable set of "official" auxiliary beliefs for Catholicism. To see why this is so, consider that while in 1095 Pope Urban II believed that an armed pilgrimage to the Holy Land (i.e. the First Crusade) was in accordance with Catholic principles, in 2000 Pope John Paul II believed the Crusades to be a "betrayal of the Gospel," one of many that he identified as having been committed in the past by those belonging to his church and for which he asked forgiveness (quoted in Stanley 2000). If we were to formulate premise 1 of the problem of religious evil as referring to Catholicism, so that it reads "belief in the God of Christianity and all of the auxiliary beliefs bound up with Catholicism," whose set of auxiliary beliefs should we take to be representative of Catholicism: those of Urban II, or those of John Paul II? No doubt it would suit Kodaj's argument to opt for the former (on the grounds that Urban II's auxiliary beliefs did result in evil), but to do so would ignore the fact that the auxiliary beliefs of a denomination can and do change over time, in which case those of John Paul II would be a better reflection of contemporary Catholic views. In fact, it would be unfair to include Urban II's views about crusading in the "official" auxiliary beliefs of Catholicism not just because they are no longer accepted, but because they have been subsequently disavowed, not just by Pope John Paul II (who appears to have described Christian violence in the Crusades as sins), ${ }^{6}$ but also by Pope Benedict, who has expressed shame over past violence committed by Christians in God's name, calling it "an abuse of the Christian faith, one that evidently contradicts its true nature" (quoted in Pullella 2011). So far as the problem of religious evil is concerned, there is nothing to stop an atheologian having premise 1 read "belief in the God of Christianity and all of the auxiliary beliefs bound up with Catholicism" where the auxiliary beliefs are those of Urban II and his followers, but all this does is enable her to defeat Urban II's vision of Catholicism, not Catholicism of today. Needless to say, defeating a version of Catholicism that no one today endorses, and in fact has been disavowed, is not much of an achievement.

\footnotetext{
${ }^{6}$ See Stanley (2000).
} 
What this suggests is that the problem of religious evil will be incapable of defeating any religion or denomination unless committing violent actions, i.e. performing evil deeds, is one of its official beliefs. With regard to Christianity (which is Kodaj's focus), I cannot think of any denomination that actually holds this. This is not to deny that there might be followers of certain denominations whose religious beliefs cause them to commit evil. However, where there are such cases one needs to determine whether the beliefs that cause the evil are official beliefs of the denomination or not. If they are not, then it cannot reasonably be said that the beliefs of that denomination cause evil, in which case the problem of religious evil cannot be used to defeat the denomination in question. Of course if one could show that the non-official or corrupted religious beliefs of one or more followers caused evil then one could potentially use the problem of religious evil to defeat the corrupted forms of religion that they hold. But it is likely to be ineffective against many (or most) non-corrupted forms of religion, given that their official beliefs do not promote evil. Nevertheless, even if the only thing that Kodaj's problem of religious evil could do is prune away corrupted forms of religions then it clearly would have some value. But whether it can perform even this limited role will depend on whether it is correct to say that religious beliefs (official or otherwise) cause evil, as its first premise contends. It is to this question that we now turn.

\section{Belief in God causes evil}

The claim that there is a causal link between religious belief and evil is a longstanding one, but although it is often made it is doubtful that those who make it actually intend it to be taken literally, which would involve investing beliefs with a genuine causal power of their own. Instead, they presumably mean that beliefs cause evil in the sense that beliefs motivate agents to perform evil deeds. In what follows, I shall continue to speak of beliefs causing or not causing evil, as for better or worse this is the language in which the debate about religious violence is often conducted, but I shall also refer to beliefs being the motivation for evil, and shall use the terms "cause" and "motivate" interchangeably. The substance of the points I wish to make remains unaffected. ${ }^{7}$

Needless to say, it remains controversial to claim that religious belief causes evil even in the sense that it "motivates" evil. A number of scholars have suggested that atheologians are too quick to pin the blame for religious evil on religion, and in so doing have ignored other factors. For instance, Gary Keogh writes (2015, p. 741): "Dawkins begins his The God Delusion ... by implying that 9/11 would have never occurred were it not for religion — a gloriously oversimplified statement ignoring the complex political history between the United States and the Middle East." 8 Keogh does not seek to deny that religious belief is a causal or motivational factor in

\footnotetext{
7 The main issue, I take it, is whether religious belief can meaningfully be implicated in the commission of evil, and it surely would be whether it functions as cause or motivation.

${ }^{8}$ For a similar view, see Shortt (2016, p. 18).
} 
religious evil; he just denies that it is the only factor (or even the main one). In suggesting this, he taps into a vein of scholarly thought that identifies religious evil-whether in the modern or pre-modern world-as the result of a complex interplay of political, economic, social, ethnic, nationalist and religious factors. ${ }^{9}$ There are those who claim that it could not be otherwise. Smith (1962, pp. 18, 19) and Cavanaugh (2009, pp. 64-69), for example, have argued that the idea of religion as a set of beliefs or practices separate from politics, culture, and other areas of life is an idea devised in the West, and relatively recently at that (taking shape between the fifteenth and seventeenth centuries). Thus "religion" as we in the West understand it today, as a phenomenon distinct from secular pursuits like politics, simply did not exist in the pre-modern West, and it does not exist now in many other parts of the world. As such, it would make no sense to lay the blame for religious evil at the feet of religious belief alone.

There are others who go further, and argue that religious evil has only political causes, and thus that religious belief is not to blame at all. Many scholars have argued that terrorist attacks, along with other instances of religious evil, are essentially politically-motivated. ${ }^{10}$ Robert Pape, for example, after investigating more than three hundred suicide terrorist attacks, claims that suicide terrorism correlates with nationalist movements against foreign occupation and oppression rather than religious fundamentalism, as is popularly believed:

The data show that there is little connection between suicide terrorism and Islamic fundamentalism, or any one of the world's religions. In fact, the leading instigators of suicide attacks are the Tamil Tigers in Sri Lanka, a Marxist-Leninist group whose members are from Hindu families but who are adamantly opposed to religion... Rather, what nearly all suicide terrorist attacks have in common is a specific secular and strategic goal: to compel modern democracies to withdraw military forces from territory that the terrorists consider to be their homeland (2005, p. 4).

Pape applies this analysis not just to the leaders of terrorist organizations, but also to those who undertake the suicide missions themselves. He argues (2005, p. 173) that suicide terrorists act out of altruistic motives, to serve the interests of their community or nation, and "accept the task much like a soldier who accepts a "suicide mission" in an ordinary war." Although he does not use the phrase himself, Pape's analysis suggests that suicide terrorism is typically carried out under the pretext of religion rather than because of religion, in spite of what the protagonists say.

\footnotetext{
9 For example, Selengut (2011, p. 94) writes: "Some cases of religious violence are so interwoven with cultural, political, and civilizational elements that they are, at their very roots, both religious and cultural." See also Al Qurtuby (2016).

10 See for example Goodin 2006, pp. 42-45. It is worth noting that terrorism is typically defined as a political rather than religious act. A catalogue of more than 250 definitions of terrorism (Schmid 2011) reveals that only a very tiny percentage of these (less than 5\%) consider religious belief to be a cause of terrorism, with the vast majority considering terrorism to be principally a socio-political phenomenon rather than a religious one. Indeed, in a much-used typology of terrorism (Marsden and Schmid 2011, p. 171), religious terrorism is considered to be a species of political terrorism.
} 
Others claim that religious belief is not itself the cause of religious violence but instead plays a different (albeit still problematic) role. Mark Juergensmeyer, for example, argues (2006, p. 141) that those engaged in religious violence often see themselves as actors in a cosmic war, with their actions divinely sanctioned, even though what ultimately lies behind the violence-its root cause-are more mundane political, economic and social factors such as "[a] sense of alienation, marginalization, and social frustration." By sacralizing their profane cause, the perpetrators of religious violence place "images of divine struggle — cosmic war-in the service of worldly political battles" (2006, p. 141). Juergensmeyer argues that religion does not cause the violence in any normal sense of the term, but the fact that it is invoked by protagonists still serves to complicate the situation dramatically, as it provides the resources to legitimize and justify violent actions and makes compromise less likely. ${ }^{11}$

We can distil the foregoing into four distinct ways of understanding the link between religious belief and religious evil ${ }^{12}$ :

(A) Religious belief is the cause of the evil

(B) Religious belief is a partial or contributory cause of the evil, the presence of which brings about evil only in conjunction with other ingredients (Keogh)

(C) Religious belief is a moderator of the true cause of the evil, interacting with the true cause in such a way as to vary the effect (Juergensmeyer)

(D) Religious belief plays no causal role in the evil (Pape)

I take it that in framing the first premise of his problem of religious evil, Kodaj was thinking of the connection between religious beliefs and evil along the lines of (A); his remark (2016, p. 278) that "violence seems endemic to religion in the sense that religious traditions and texts appear to inspire violence regularly and with great effectiveness" seems to suggest that also.

However, option (A) could mean many different things, for example that religious belief is a necessary cause of evil, or a sufficient cause, or a sole cause (i.e. both necessary and sufficient). ${ }^{13}$ Kodaj does not say enough for us to be able to ascertain which of these best reflects his thinking, though ultimately this does not matter as all three ways of understanding option (A) can be rejected. First, if religious belief were a necessary cause of religious evil, then religious evil would not occur without religious belief. But the fact that an evil is committed ostensibly in the name of God does not entail that religious belief was behind it, since religion may be used as a pretext for violence, as many have noted. ${ }^{14}$ Accordingly, religious belief cannot be a necessary cause of religious evil. Second, if religious belief were a sufficient cause of evil, then religious belief would guarantee the occurrence of

\footnotetext{
${ }^{11}$ In a similar vein, Keith Ward claims (2006, p. 81) that the root causes of the Israeli-Palestinian conflict are social and political, but that religion "fuels the conflict" because it is used a "marker of identity."

12 In what follows I utilize the terminology and descriptions (conjunctive cause, moderator) from Steinberg, Layne and Steinberg (2011, pp. 180-190).

13 I remind the reader again that "cause" may here be understood in the sense of "motivation" or "motivating factor."

${ }^{14}$ For example, the Archbishop of Canterbury, Welby (2016), and even Harris (2005, p. 137).
} 
evil. But this can be rejected on empirical grounds, simply by noting that there are (and have been) many people with theistic belief who have not engaged in the sort of practices Kodaj describes as evil. As Asad (2003, p. 10) bluntly put it, "One need only remind oneself of the banal fact that innumerable pious Muslims, Jews, and Christians read their scriptures without being seized by the need to kill nonbelievers." So religious belief cannot be a sufficient cause of evil. Lastly, if religious belief were a sole cause of evil, then there would be no other factors involved. But this can be rejected on the grounds of sheer implausibility: to say that there were no political, economic, ethnic, or nationalistic factors in evil often labeled as "religious" (such as the Troubles in Northern Ireland, the IsraeliPalestinian conflict, or the Bosnian war) is simply too fantastic to take seriously. ${ }^{15}$ Consequently, despite its popularity in the polemical atheistic literature and in the Western media, ${ }^{16}$ it is implausible to claim that religious beliefs cause evil, no matter whether we take "cause" to mean necessary cause, sufficient cause, or sole cause.

This means that when such evil does occur, religion must be either a partial or contributory cause (option B above), or a moderator (C), or have no causal role whatsoever (D). I take it that if (B) is the case then it would still be technically correct to say that religious belief causes evil, though for the sake of clarity premise 1 of Kodaj's argument would have to be reformulated as "religious belief is a partial or contributory cause of evil." This strikes me as sufficient for the problem of religious evil to operate in the way Kodaj intended, as a defeater of certain forms of religious belief. However, as his problem of religious evil hinges on religious beliefs causing evil, it would seem to fail outright if either option (C) or (D) best describes the relation between religion and evil, for under (C) and (D) it would not be correct to say that religious belief causes evil. ${ }^{17}$

The potential success or failure of the problem of religious evil thus depends on whether option B, C, or D is the most plausible way of characterizing the relationship between religious belief and evil. Unfortunately this is not something that the philosopher can easily judge, as it is not a philosophical matter; ultimately it is something for the sociologist, anthropologist, and political scientist to decide, and

\footnotetext{
15 Another way to defeat the claim that religious belief is the sole cause of evil would be to acknowledge, in the words of Armstrong (2014, p. 359), that "Identical beliefs and practices have inspired diametrically opposed courses of action." She observes, for example, that "In the Hebrew Bible, the Deuteronomists and the Priestly authors all meditated on the same stories, but the Deuteronomists turned virulently against foreign peoples, while the Priestly authors sought reconciliation... Saint Luke and the Johannine authors all reflected on Jesus's message of love, but Luke reached out to marginalized members of society, while the Johannines confined their love to their own group." This suggests that the beliefs alone cannot be the cause of evil, and that one needs to consider other factors (such as the prevailing political and economic circumstances, the presence or absence of external threats, individual psychologies etc.) to explain why it occurs when it does.

16 On the Western media's often unsophisticated representation and/or portrayal of religiously-inspired violence, see Mitchell (2011).

17 Of course the situation may be more complicated than this: it may be that some instances of religious evil are most adequately described under (B), some under (C), and some under (D). Selengut (2011, p. 92) gestures in this direction when he argues that while some religious violence does have its roots in religious belief, some does not, instead being the product of political or ideological claims which are given a religious spin in order to increase their legitimacy.
} 
as we have seen there is no consensus among them about this. But note that it is not the mere existence of disagreement that is the problem, but the scale of it. The situation is thus this: some people claim that belief in God causes evil. The onus of proof is squarely on those who make such a claim. So how would they prove it? They could try to justify such a claim by pointing to the work of sociologists/ anthropologists/political scientists, whose domain it is, but the work of sociologists/ anthropologists/political scientists does not unambiguously support the claim they wish to make; in fact, much of it points away from this claim. Therefore, absent any other proof, the claim is unsafe.

This is a significant complication for the atheologian who would make use of the problem of religious evil to defeat various religions and denominations, as it renders the first premise of the argument ("belief in God causes evil") entirely uncertain, and as such not a particularly secure foundation upon which to base the rest of the argument. Unless and until the matter about the connection between religious belief and evil is resolved, and the reasonableness (or otherwise) of premise 1 of Kodaj's argument established, his argument is reduced to being hypothetical in nature. That is, it effectively says: if religious belief causes evil, then (in accordance with the remaining premises) one should refrain from religious belief. But of course such a reconfigured argument would be no epistemic or normative defeater of any strain of religious belief, official or otherwise. ${ }^{18}$

\section{Belief in God causes evil}

We turn now to the third and final problem with the claim that "belief in God causes evil," this one concerning the notion of evil that Kodaj employs. As we have seen, Kodaj defines evils as acts or practices that bring about harm, and religious evils as those evils committed in God's name. On the surface, it would seem that the least controversial part of the idea that "belief in God causes evil" is that some believers

\footnotetext{
${ }^{18}$ It is worth noting what Kodaj has to say in response to those who claim that belief in God is not a cause of evil. If such a claim is true, he argues, then it must be the case that belief in God does not stop people from perpetrating horrible evils, which Kodaj describes as "an epistemic defeater of theism" in its own right, on the grounds that "it casts doubt on the power of faith to motivate sinless behaviour" (2014, p. 430). It is unclear whether Kodaj thinks that correct religious beliefs should have a kind of magical hold over the faithful, guaranteeing that they do no wrong, or whether correct religious beliefs should simply motivate the faithful to sinlessness through normal psychological processes. Either way, Kodaj seems to suppose that religious beliefs should be a sufficient cause of good actions, and the fact that they are not reflects badly on religion. But this seems an odd claim to make, inasmuch as many religions themselves assume that belief cannot or will not motivate sinless behavior, and even build this assumption into their practices. All Abrahamic religions have specific procedures for sinners to repent and beg forgiveness, either through a direct appeal to God or through an appointed intermediary. These practices would be entirely redundant if belief were taken to have the sort of power Kodaj thinks it should. In the great religious traditions, belief has never been thought of as an insulator or guarantor against sinfulness, and to suggest that it should serve as such is naïve and unrealistic. Moreover, the Christian tradition (which is Kodaj's chief target) accepts the inevitably of sin-of believers and non-believers alike-on account of the doctrine of original sin. As Chesterton (2002, p. 67) once wryly observed, given the long history of human depravity, the doctrine of original sin "is the only part of Christian theology which can really be proved." It would therefore be an odd objection to the Christian tradition that belief does not motivate sinless behavior given that, by its own tenets, sinlessness is not even possible.
} 
do actually bring about evil (in the sense of causing harm), and do so ostensibly in God's name. Nevertheless, a closer examination of Kodaj's notion of evil will reveal shortcomings.

Kodaj states (2016, p. 277) that his reason for adopting what he describes as his "relatively liberal conception" of evil "is purely pragmatic: it covers the cases that are routinely cited in the literature and in public discourse as evidence that religion (or some form of it) is harmful." In other words, Kodaj's preferred notion of evil is drawn from anti-theistic literature and discussions; as such, his choice of that particular notion of evil, given the bent of the literature which inspired it, looks to be a breach of the principle of charity, which requires one to present an opponent's position as sympathetically as possible. The breach occurs because, by Kodaj's own admission (2016, p. 277), his notion of evil differs from that favored by many theists. Traditionally, of course, theism has recognized two distinct types of "evil": moral evil (sin, or wickedness), and natural evil (harm brought about by natural processes, such as disease, earthquakes, drought etc.). ${ }^{19}$ Kodaj's notion of religious evil and the traditional category of moral evil coincide, but only up to a point: both concern human actions, and both would deem many of the same actions to be evil, but some actions that would be deemed evil under one notion would not be deemed evil under the other, and vice versa. For example, Kodaj's notion of evil would not deem someone's deliberate rejection of God to be evil because no individuals or social groups are harmed by it, but the rejection of God would qualify as a moral evil if a religion designates it as such. Conversely, Kodaj's notion of evil would deem the act of harming an aggressor who threatens one's religion to be evil, as by definition it results in harm, but the act would not qualify as a moral evil if the religion in question does not designate it a sin. In important cases, then, one who endorses the notion of moral evil and one who endorses Kodaj's notion of evil may disagree about what qualifies as evil. ${ }^{20}$ And needless to say, much of the disagreement is likely to focus on precisely those sorts of cases that Kodaj would take to be paradigm examples of religious evils.

Arbitration in such cases is not likely to be successful. The reason for this, of course, is that Kodaj's notion of evil takes its cue from the secular morality of Western modernity rather than that of any of the religions he is seeking to defeat. This means that the secularist is talking a different moral language from that of the theist, inasmuch as secular morality is principally concerned with increasing wellbeing and reducing suffering (hence why in the secular sphere evil may be plausibly defined as bringing about harm), while a religious morality, at least in a Christian context, is principally concerned with aligning oneself morally and spiritually with God (hence why evil in the theistic sphere is defined as $\sin$ ). Secularists are often adamant that the secular morality of Western modernity is superior to any form of morality grounded in religion, and as such should function as arbiter of what is right

\footnotetext{
${ }^{19}$ See for example Hick (2010, p. 12) and Swinburne (1998).

${ }^{20}$ It is worth noting that much of the literature on the topic uses the expression "religious violence," which is a much more neutral term than "religious evil," since "violence" is usually a descriptive term while "evil" is typically evaluative, being used to describe actions that are blameworthy and unjustified. Needless to say, those who endorse the notion of moral evil could and presumably would still accept that an act of religious violence causes harm, or is violent, even if they deny that it qualifies as evil.
} 
and wrong, and good or evil. ${ }^{21}$ Theists who accept a religious morality would surely disagree, and insist that their form of morality is superior, and consequently the true arbiter of good or evil. The disagreement is a deep one, and cannot be settled simply by one side claiming moral superiority over the other, though in practice that is often what happens. ${ }^{22}$ The upshot is that theists can quite reasonably reject Kodaj's entire argument on the basis that it utilizes a secular rather than theistic notion of evil, and thus improperly designates as evil certain actions which are in fact not. This is surely a significant setback for the problem of religious evil, inasmuch as Kodaj's argument is clearly designed to force theists to give up their religious beliefs. In practice, though, it could achieve this only if theists are prepared to favor the secular notion of evil over the theistic notion, but as the argument does not give them a reason to do this, it is not clear why they would.

\section{Conclusion}

Over the course of this paper we have seen that there are a number of problems with the idea that belief in God causes evil, and thus with Kodaj's attempt to use this idea as the basis for a pro-atheistic argument. The problems have revealed that the argument could only succeed against those denominations whose official beliefs include the committing of evil actions, and only then if it could be determined that the beliefs in question were a contributing causal or motivating factor to those actions. Its success also depends on one's willingness to endorse a secular notion of evil, which theists could not plausibly be expected to do. Accordingly, the prospects for a pro-atheistic argument based on religious evil do not strike me as good. Any such argument would have to be based on the idea that belief in God causes evil, or something very similar, but even with the sort of modifications to it suggested in this paper, the idea is still too problematic to do anything other than diminish the strength of any argument that relies upon it. Despite that, there is something unsettling about religious evil, and it is surely right to ask how much of a role religion plays in it, and how religions intend to square it with their own vision of the universe and man's role therein. This could lead to uncomfortable questions for certain religions or denominations thereof, but not, I suspect, to a decisive objection against them.

Acknowledgements I would like to thank Blandina Chaza, Shandon Guthrie, Gary Keogh, Matthew Rowley, Charles Taliaferro, and an anonymous referee for helpful comments on an earlier version of this paper.

\footnotetext{
${ }^{21}$ For example, Coyne (2015, p. 261) claims that "secular morality, which is not twisted by adherence to the supposed commands of a god, is superior to most "religious" morality." Kodaj appears to accept this, for the tentative "partial" solution he offers (2014, p. 442) to his own problem of evil involves a combination of three distinct ideas, namely: "(1) secular morality trumps religiosity, (2) perpetrators of religious evil are not genuinely religious, and (3) salvation depends primarily on (secular) morality, not on religiosity."

${ }^{22}$ Not always, however. For an attempt to argue for the superiority of a religious morality see Mavrodes (1986), and for an attempt to argue for the superiority of a secular morality, see Harris (2005, pp. 170-203).
} 
Open Access This article is distributed under the terms of the Creative Commons Attribution 4.0 International License (http://creativecommons.org/licenses/by/4.0/), which permits unrestricted use, distribution, and reproduction in any medium, provided you give appropriate credit to the original author(s) and the source, provide a link to the Creative Commons license, and indicate if changes were made.

\section{References}

Al Qurtuby, S. (2016). Religious violence and conciliation in Indonesia: Christians and muslims in Moluccas. London: Routledge.

Armstrong, K. (2014). Fields of blood: Religion and the history of violence. London: Penguin.

Asad, T. (2003). Formations of the secular: Christianity, Islam, modernity. Stanford: Stanford University Press.

Buijs, J. A. (2009). Atheism and the argument from harm. Philosophia Christi, 11(1), 42-52.

Canadian Security Intelligence Service. (2002). Doomsday religious movements. In J. Kaplan (Ed.), Millennial violence: Past, present and future (pp. 53-60). London: Frank Cass.

Cavanaugh, W. T. (2009). The myth of religious violence: Secular ideology and the roots of modern conflict. Oxford: Oxford University Press.

Chesterton, G. K. (2002). In M. W. Perry (Ed.), Chesterton day by day. Seattle: Inkling Books.

Coyne, J. A. (2015). Faith versus fact: Why science and religion are incompatible. London: Penguin.

Dawkins, R. (2006). The God delusion. London: Bantam Books.

Draper, P., \& Nichols, R. (2013). Diagnosing bias in philosophy of religion. The Monist, 96(3), 420-446.

Everitt, N. (2004). The non-existence of God. London: Routledge.

Goodin, R. E. (2006). What's wrong with terrorism?. Cambridge: Polity.

Harris, S. (2005). The end of faith: Religion, terror, and the future of reason. London: Simon \& Schuster. Hick, J. (2010). Evil and the God of love (2nd ed.). Basingstoke: Palgrave Macmillan.

Hitchens, C. (2007). God is not great. London: Atlantic Books.

Hume, D. (1793). Essays and treatises on several subjects (vol. IV). Basil: J. J. Tourneisen.

Jones, J. W. (2008). Blood that cries out from the Earth: The psychology of religious terrorism. Oxford: Oxford University Press.

Juergensmeyer, M. (2006). Religion as a cause of terrorism. In L. Richardson (Ed.), The roots of terrorism (pp. 133-144). London: Routledge.

Keogh, G. (2015). Theology after new atheism. New Blackfriars, 96(1066), 739-750.

Kodaj, D. (2014). The problem of religious evil. Religious Studies, 50(4), 425-443.

Kodaj, D. (2016). Religious evil. Philosophy Compass, 11(5), 277-286.

Le Poidevin, P. (1996). Arguing for atheism. London: Routledge.

Lucretius. (2007). The nature of the universe (A. E. Stallings, Trans.). London: Penguin.

Marsden, S. V., \& Schmid, A. P. (2011). Typologies of terrorism and political violence. In A. P. Schmid (Ed.), The Routledge handbook of terrorism research (pp. 158-200). London: Routledge.

Mavrodes, G. I. (1986). Religion and the queerness of morality. In R. Audi \& W. J. Wainright (Eds.), Rationality, religious belief and moral commitment: Essays in the philosophy of religion (pp. 213-226). Ithaca: Cornell University Press.

Mitchell, J. (2011). Mediating religious violence. In A. R. Murphy (Ed.), The Blackwell companion to religion and violence (pp. 112-124). Oxford: Blackwell.

Nelson-Pallmeyer, J. (2003). Is religion killing us? Violence in the Bible and Quran. Harrisburg: Trinity Press International.

Oppy, G. (2013). Arguments for atheism. In S. Bullivant \& M. Ruse (Eds.), The Oxford handbook of atheism (pp. 53-70). Oxford: Oxford University Press.

Pape, R. A. (2005). Dying to win: The strategic logic of suicide terrorism. New York: Random House.

Pullella, P. (2011). Pope Benedict expresses shame for Christian violence in history. Reuters. http://blogs. reuters.com/faithworld/2011/10/28/pope-benedict-expresses-shame-for-christian-violence-inhistory/. Accessed 10 Feb 2017.

Rowley, M. (2014). What causes religious violence? Three hundred claimed contributing causes. Journal of Religion and Violence, 2(3), 361-402. 
Russell, B. (1957). Why I am not a Christian. London: Routledge.

Schmid, A. P. (2011). The definition of terrorism. Appendix 2.1: 250-plus academic, governmental and intergovernmental definitions of terrorism. In A. P. Schmid (Ed.), The Routledge handbook of terrorism research (pp. 39-157). London: Routledge.

Selengut, C. (2011). The sociology of religious violence. In A. R. Murphy (Ed.), The Blackwell companion to religion and violence (pp. 89-98). Oxford: Blackwell.

Shortt, R. (2016). God is no thing. London: Hurst \& Company.

Smith, W. C. (1962). The meaning and end of religion. New York: Macmillan.

Stanley, A. (2000). Pope asks forgiveness for errors of the church over 2000 years. New York Times. http://www.nytimes.com/2000/03/13/world/pope-asks-forgiveness-for-errors-of-the-church-over2000-years.html?pagewanted=all. Accessed 10 Feb 2017.

Steinberg, J. R., Layne, C. M., \& Steinberg, A. M. (2011). Ceteris paribus causal generalizations and scientific inquiry in empirical psychology. Journal of Theoretical and Philosophical Psychology, 32(3), 180-190.

Swinburne, R. (1998). Providence and the problem of evil. Oxford: Clarendon Press.

Ward, K. (2006). Is religion dangerous?. Oxford: Lion Hudson.

Welby, J. (2016). Lecture: 'The Generational Struggle'-ending religiously justified violence. http:// www.archbishopofcanterbury.org/articles.php/5667/lecture-the-generational-struggle-endingreligiously-justified-violence. Accessed 10 Feb 2017.

Wellman, J. K., Jr., \& Tokuno, K. (2004). Is religious violence inevitable? Journal for the Scientific Study of Religion, 43(3), 291-296.

Young, J. (2008). The violence of god and the war on terror. New York: Seabury. 